\title{
A Trade Union Approach to Climate Justice: The Campaign Strategy of the National Union of Metalworkers of South Africa
}

\author{
Vishwas Satgar, University of the Witwaterstand, South Africa
}

\begin{abstract}
South Africa is the twelfth highest emitter of carbon emissions in the world. It has an energy intensity and per capita usage of fossil fuel energy that surpasses other countries in the BRICS, it is currently building one the largest coal-fired power stations in the world, and is championing a green neo-liberal approach to the climate change crisis. This article investigates how the National Union of Metal Workers of South Africa (NUMSA) developed an approach to climate justice and is intervening to shape policy around the just transition in South Africa. The article explores the factors that contributed to NUMSA's embrace of a politics of climate justice, the internal education and policy capacity developed in the union and the campaigns championed to advance climate justice. The article provides insights into how NUMSA has campaigned around energy efficiency and electricity price increases, influenced and monitored the roll out of solar water geysers and has advanced a position on socially owned renewable energy.
\end{abstract}

\section{Introduction}

The National Union of Metalworkers of South Africa (NUMSA) has one of the most developed trade union responses to climate change in South Africa and in the African context more broadly. The union is evolving its position, which has been shaped by the broader policy approaches in the country to address climate change, the politics of climate justice activism, the sectoral challenges of de-industrialisation and manufacturing-centred carbon emissions, particularly through huge smelters. NUMSA is a union steeped in the tradition of worker control and has consistently attempted to forge a left orientation in its political positions on a wide range of issues. This practice of worker control and commitment to a left orientation has ensured that the union is able to work through strategic challenges and questions by utilising internal worker education, collective debates, technical capacity building and policy interventions in the policy-making process of the country. Its approach to climate justice and its concrete campaign strategy is grounded in and continues with this tradition.

The climate justice campaign strategy adopted by NUMSA works simultaneously on different fronts. It seeks to ensure that the needs of workers and communities are met while attempting to address the challenges of climate change. This has entailed contesting electricity price increases, seeking to influence the procurement and rollout of solar water heaters, and advancing an agenda to achieve socially owned renewable energy options. This broad climate justice campaign strategy has brought both successes and challenges to the union.

This article looks at how the union is evolving and taking forward a campaign for climate justice in South Africa.

Global Labour Journal, 2015, 6(3), Page 267 


\section{The Environment, Climate Injustice and Trade Unions}

Across the world, trade union politics have generally focused on workplace issues to ensure improved wages and working conditions for their members. In general labour has merely understood nature as a 'conquered' and limitless source of raw materials as a production input or as external to the production process, either commodified by capital or as a space to be enjoyed (Räthzel and Uzzell, 2013). As a consequence, environmental movements have consistently critiqued labour for merely defending productivist positions (more production for higher output, incomes and growth) while being blind to the impacts on nature. Where there has been a convergence of environmental and union politics, this has been mainly around health and safety issues. Pollution and its impacts on workers, factories and the environment have served to bring together environmental and labour movements. However, this intersection has not been sufficient to weld together a sustained and strategic green-red politics that incorporates both social justice and ecological issues.

It is in this context that climate change, both its challenges and politics, becomes crucial for building trade union and environmental alliances. With a growing realisation that climate change cannot be ignored and is becoming part of planetary lived experience, labour is challenged to develop an appropriate response. This is also prompting a rethink with regard to labour and its relationship to nature, and more fundamentally to labour politics that can go beyond productivism. Central to this is a realisation that climate change will exacerbate social inequalities and will also have disproportionate social impacts because of the existence of social inequalities both between and within countries. Moreover, it has become patently clear that rich countries have a historical responsibility in relation to carbon emissions and human-induced climate change. There is a climate debt at stake here that rich countries have to address to enable poor countries to adapt and mitigate climate change (Bond, 2011, 2012). This throws up a serious challenge for North-South trade union solidarity. It prompts unions to think beyond local issues, to think in terms of the connections between the local-global/global-local, and to appreciate how climate change features at both levels as cause, effect or impact.

Moreover, the transition required of economies and societies to deal with climate change prompts a serious rethink about how production, consumption, jobs and climate change need to be addressed. Work provides workers with income, dignity and the means to survive. To address climate change in a way that ensures that workers, the poor and the excluded do not pay the costs of ecological restructuring of economies is crucial. Climate change cannot be about climate injustice for workers such that workers have to pay the price. The adaptation and mitigation of climate change have thrown up several challenges that go to the heart of global inequality. First, merely providing technocratic solutions, including carbon trading and geo-engineering, is not going to solve the climate crisis. These have proven to be false solutions which carry more risks for workers and the poor, and simply provide avenues for further wealth creation for large corporations at the expense of workers and the poor. Second, merely transforming energy systems away from fossil fuels to renewables and shifting to public transport systems, while absolutely crucial and important, do not in themselves address the scale and depth of the systemic change required to address the climate crisis. There is a growing recognition that human societies have to ensure fundamental ecological restructuring of production, consumption and general ways of living to survive climate change. Real mitigation and adaptation means a rejection of false technocratic and market-based solutions so that systemic transformation is advanced in order to address climate change while simultaneously ensuring the needs of workers, the poor and underdeveloped countries come first. This is the crux of what climate justice means and what defines climate justice as a movement and a form of politics today. ${ }^{2}$

Global Labour Journal, 2015, 6(3), Page 268 
It is in this context that the global trade union movement has entered the debate about climate change and climate justice. This is a recent development and was given momentum after an assembly of unions from all over the world took place in Nairobi in 2006 to engage with the challenge of environmental issues. Increasingly unions have begun to take on policies and develop capacities to address the link between climate, jobs and new forms of production. Moreover, there is a very crucial strategic perspective coming to the fore among unions for a just transition and 'green jobs' (Cock, 2013). This has unleashed serious debates on the depth of change as part of the response to the climate crisis. On the one hand, some unions are calling for green jobs and a green economy to end the dichotomy between jobs and climate while, on the other hand, some unions are building more transformative policy and strategic positions on climate change that recognise the system as the problem. This is best captured in the slogan: system change not climate change. This notion is also at the heart of climate justice politics today. For unions serious about system change as a basis for addressing the climate crisis, this poses three crucial challenges. First, it is necessary to recognieg that unions' strategic practices have to evolve a politics that marries members' immediate interests to the interests of society and nature. To do this, unions have to build capacities, educate their members and develop appropriate policies. Second, a red-green alliance or convergence of the trade union movement and the environmental movement around a politics of transformative alternatives is crucial. This has to entail solidarities around defensive and offensive struggles to ensure that climate justice positions come to the fore in society, which will also have implications for party and state engagements in different contexts. Third, unions have to grapple with the challenge of transnational solidarity around just transitions in national contexts, while impacting on global production, trade and financial structures.

Flowing from this is a focus on South Africa's fossil-fuel-driven economy, trade union responses and the challenge of addressing climate change through a climate justice politics. In this regard, this article will assess the role of NUMSA in developing a union approach to climate justice.

\section{South Africa's Fossil-fuel-Driven Economy and Climate Change}

South Africa has a carbon-intensive economy, with about $85 \%$ of electricity generated from coal. Currently South Africa emits 511 million megatonnes of carbon a year, almost half of this coming from Eskom, the country's national electricity-producing parastatal (Urban Earth, 2012). The sectoral breakdown of direct carbon emissions shows a concentration of polluters in minerals, energy, industry and transport: mining energy (51\%); industrial energy consumption ( $9 \%$ ); industrial processing (14\%); transport (9\%); agriculture, forestry and other land uses $(6 \%)$; fugitive emissions $(9 \%)$; waste $(2 \%){ }^{3}$ While South Africa contributes 1.49\% of total global $\mathrm{CO}_{2}$ emissions, its per capita emissions are 9.18, even higher than its BRICS partners China (5.83), Brazil (2.11), and India (1.38) (Urban Earth, 2012: 7). Despite government commitments to United Nations (UN) multilateral processes to bring down carbon emissions, it is still the twelfth highest emitter of carbon in the world and the highest in Africa, responsible for $40 \%$ of emissions on the continent (Urban Earth, 2012).

According to the Organisation for Economic Cooperation and Development (OECD), South Africa is one of the most energy-intensive middle-income countries in the world and is lagging behind world targets in terms of reducing this intensity. The countries in the BRIC grouping (Brazil, Russia, India and China) dropped their intensity by $24 \%$ in the 2000 s, but South Africa managed only 9\% (Kings, 2013: 6). Part of the challenge facing South Africa's carbon-intensive economy is the abundant supply and low industrial pricing of electricity. While electricity prices have been moving upwards over the past few years, ${ }^{4}$ this has not been managed in a sustainable manner to ensure that the general cost structure of the economy is not overinflated. Moreover, the transition

Global Labour Journal, 2015, 6(3), Page 269 
from a carbon-intensive economy to a low-carbon economy is fraught with various obstacles.

South Africa's response to climate change has been determined by its embrace of 'long-term mitigation scenarios' (Winkler, Undated). In 2008 the Cabinet adopted these scenarios, which provide for a peak, plateau and decline approach. In summary, the National Climate Change Response White Paper states:

- 'South Africa's GHG [greenhouse gas] emissions peak in the period 2020 to 2025 in a range with a lower limit of 398 megatonnes $\left(10^{9} \mathrm{~kg}\right)(\mathrm{Mt}) \mathrm{CO}_{2}$-eq and upper limits of 583 Mt $\mathrm{CO}_{2}$-eq and $614 \mathrm{Mt} \mathrm{CO}_{2}$-eq for 2020 and 2025, respectively.

- 'South Africa's GHG emissions will plateau for up to ten years after the peak within the range with a lower limit of $398 \mathrm{Mt} \mathrm{CO}_{2}$-eq and an upper limit of $614 \mathrm{Mt} \mathrm{CO}_{2}$-eq.

- 'From 2036 onwards, emissions will decline in absolute terms to a range with a lower limit of $212 \mathrm{Mt} \mathrm{CO}_{2}$-eq and an upper limit of $428 \mathrm{Mt} \mathrm{CO}_{2}$-eq by 2050' (South African Government, 2011:27).

In other words, as part of ensuring that South Africa contributes to limiting temperature increases to two degrees Celsius above preindustrial levels, the country has to make a $34 \%$ reduction in its emissions trajectory by 2020 , followed by a $42 \%$ reduction by 2025 . However, reaching these targets is contingent on technology as well as financial and capacity-building support from the rich developed countries. Further, with the embrace of the Copenhagen Accord, South Africa locked itself into a pledge and review approach, supported by market mechanisms embedded within the Kyoto Protocol. Within the UN process, the Clean Development Mechanism (CDM) provides for the certification of clean development projects in developing countries and then issues carbon credits (Certified Emission Reductions). These credits are then traded with buyers in the Global North to offset their emissions. CDM is meant to encourage the use of clean technology and the reduction of emissions. This is about market-based mitigation of carbon emissions and in some senses is also an adaptation tool when technology and institutional change is introduced.

The role of the CDM in South Africa has been limited and since 2004, when projects came on stream, very few have secured carbon credits. According to Newmarch (2013: 40), only twenty-one projects out of 326 have been registered as carbon offset projects and just nine are receiving carbon credits. This is in a context in which carbon trading internationally has not been able to ensure significant emission reductions. Moreover, the limited domestic experience with CDM offsets and carbon credits suggests that they have not worked and have created various ecological and social problems (Bond, 2012). ${ }^{5}$ Nonetheless, the push to make sure South Africa locks into carbon trading and speeds up its support for the Clean Development Mechanism is coming through the National Development Plan - 2030 (NDP); the NDP strengthens the CDM approach embedded in the National Climate Response White Paper (South African Government, Undated: 208-9, 2011b). On the mitigation side, the NDP push centres on an approach it calls 'carbon costing'. This would enable two policy instruments to form the basis for a carbon pricing strategy led by an alliance between the state and the private sector. The first such policy instrument is carbon pricing (setting the unit cost of carbon) and the second is carbon budgeting for each sector of the economy. The NDP then calls for active support by the Johannesburg Stock Exchange to ensure that a domestic market is in place for carbon offsets.

While Africa as a whole is predicted to have at least a two-degree increase in temperatures in the coming years, South Africa will also be affected by this, and dramatic impacts are anticipated. In this context the National Climate Change Response White Paper is a positive development, recognising that the failure to address climate change will be more costly and complex in the future.

Global Labour Journal, 2015, 6(3), Page 270 
The White Paper is alive to adaptation challenges and the need to have early warning systems, including integrated planning and a focus on priority areas such as water, agriculture, health, biodiversity and ecosystems, human settlements, and disaster risk management. At the same time, the main policy outcomes envisaged in the context of climate-change mitigation and adaptation echoes the discourse on green jobs and the green economy, in particular emphasising these as outcomes. While these concepts are not precisely defined, they suffuse the policy rhetoric of the White Paper.

South Africa's approach to the climate challenge can best be characterised as 'green neoliberalism' (Satgar, 2014). While acknowledging the climate change challenge, South Africa is embracing an accumulation path that does not decouple growth but rather affirms the polluting and environmentally destructive minerals-energy complex; it affirms market mechanisms as the best way to bring down emissions and supports a private-sector-led approach to renewable energy. For a progressive union like NUMSA the shift to green neo-liberalism in South Africa, with its emphasis on green jobs, accumulation, finance and growth, necessitates the need for serious alternatives. It requires a strategic union politics to contest such a dominant discourse which will continue to produce social and environmental inequality.

\section{Developing a Strategic Union Position on Climate Change}

NUMSA did not always have a conscious position on climate change, let alone climate justice. But like any dynamic union alive to changing domestic and global circumstances, it took up the challenge to inform itself about climate change. This was shaped by various factors and evolved over a few years. The first crucial factor had to do with macro-policy debates around climate change and energy policy. In particular when the South African government issued its White Paper on Climate Change (South African Government, 2011) issues around climate change entered the national debate. The document brought to the fore a set of imperatives for mitigation and adaptation. At the same time, the South African government committed to host the UN Conference of the Parties Summit (COP 17) in November 2011. As part of the build-up to this event, the government issued its climate change scenarios, which called for a rise, plateau and decline approach to carbon emissions. Accompanying this suite of policies was the Integrated Resource Plan (IRP), which brought to the fore a national debate on South Africa's energy mix. The IRP provides for a twentyyear energy plan, made up predominantly of a coal-fired energy path $(65 \%$ coal-generated energy by 2030 , down from its current $85 \%$ ), complemented by nuclear $(20 \%)$, hydro $(5 \%)$, renewables $(9 \%)$ and other sources. The need for a strong union perspective on South Africa's energy future became crucial.

In this context the trade union movement in South Africa and NUMSA in particular found itself on the back foot. As part of South Africa's macroeconomic corporatist bargaining arrangements, the big three - government, business and unions - enter into dialogue around national policies en route to Parliament in a forum called the National Economic Development and Labour Council (NEDLAC). In this macro context NUMSA realised the need to fill a policy lacuna in its own ranks and more broadly in the union federation, the Congress of South African Trade Unions (COSATU). In the latter part of 2010 the union decided to host a seminar to inform itself about these issues and to initiate the development of a union position. This seminar unpacked various issues around South Africa's energy mix, the challenges of nuclear power and fossil fuels, and the need for a union approach to COP 17, particularly on issues related to mitigation and adaptation. It was at this seminar that the union decided to establish its Research and Development Groups (RDGs), to assist it in elaborating and clarifying its policy positions.

At the same time, the build-up to COP 17 began to mobilise South African civil society, which

Global Labour Journal, 2015, 6(3), Page 271 
provided a second crucial factor propelling NUMSA to take climate change seriously. At least one initiative, the One Million Climate Jobs Campaign, developed a research focus on the carbon footprint of the South African economy and the transition to climate jobs. NUMSA supported this research with a research submission; the campaign was also endorsed by NUMSA and COSATU. The Campaign hosted a successful international conference on Climate Jobs at the COP 17 'People's Space'. The entire politics around COP 17, climate justice and the challenges of securing a serious agreement on climate change also challenged NUMSA. The failure of the South African government to unite with Africa and its willingness to affirm the Obama-led pledge and review approach also served to raise concerns in NUMSA about how South Africa was going to take forward both its mitigation and adaptation challenges.

At the same time, NUMSA had to face major structural challenges in the manufacturing sector of the South African economy. As South Africa liberalised and globalised its economy, the country had been deindustrialising. This meant thousands of jobs were lost in a shrinking manufacturing sector, the core of NUMSA's membership base. With the onset of the global crisis, engendering a decline in global demand and introducing volatility in South Africa's exchange rate, NUMSA started looking for a strategic way forward. With a proactive and transformative approach in mind, the union approached the crisis as an opportunity. While NUMSA does not organise in energy generally, it does have membership in South Africa's largest electricity provisioning parastatal, Eskom. This then brought to the fore an interesting set of issues around climate change, energy and economic restructuring for NUMSA at a strategic level. To protect local industries, strengthen manufacturing capabilities and increase localisation, NUMSA began to formulate policy positions it could take into COSATU and more broadly into the national policy-making process.

Hence in June 2012, after building a great deal of awareness in its ranks, NUMSA adopted the following resolutions at a national congress to guide its positions on climate change and climate justice more broadly:

- Climate Change and Class Struggle (NUMSA, 2012b) - This resolution explicitly commits NUMSA to finding climate justice solutions from below as part of struggling for a deep transition to a low-carbon economy based on renewable energy sources. The resolution recognises that the state, in the light of the failings of the COP process, is not capable of delivering serious responses to climate change mitigation and adaptation.

- Building a Socially Owned Renewable Energy Sector in South Africa (NUMSA, 2012a) - Central to the political economy of a just transition is a political commitment to build a socially owned renewable energy sector which is made up of different forms of socialised property cooperatives, municipal ownership and socialised parastatals. Such a sector should also ensure the promotion of locally manufactured renewable energy technologies.

However, in addition to these resolutions, the internal developments, capacity building and campaigning informing these resolutions also have to be brought into view in order to understand NUMSA's evolving approach to climate justice. Put differently, to arrive at these resolutions the union went through an internal process of deliberation, research and decision making involving worker-controlled processes from above and below in the union. This was further cemented as the union engaged in grassroots campaigning against increases in electricity prices, to secure energy efficiency gains under worker control, for domestic solar water heater manufacturing and for socially owned renewables within the national energy mix. We turn to these issues to understand how the union evolved its position and approach to climate justice.

Global Labour Journal, 2015, 6(3), Page 272 


\section{Building Union Capacity to Respond to Climate Change}

\section{Research and development groups}

In August 2010, in the midst of confronting the challenges of energy and climate change policy debates in the country, NUMSA established Research and Development Groups(NUMSA, 2011). These RDGs brought workers together from three sub-sectors: (i) renewable technology production (such as solar water heaters); (ii) Eskom, the coal-fired electricity generator and distributor in South Africa; and (iii) the intensive energy users (smelters like SCAW Metals, ArcelorMittal, BHP Billiton and Asmang Ferrachrome). Initially the RDGs were formed around concerns raised by workers and the interests of the NUMSA head office around energy issues.

A number of different concerns were raised by different groups of workers from different sectors. On the one hand, workers in renewable technology production were concerned about cheap imports, Eskom workers were concerned about the corporatised nature of their workplace, and workers from the intensive energy users were concerned about increases in energy prices and their jobs. On the other hand, the head office of NUMSA was keen to establish whether workplaces had energy committees, the competencies of these committees, and whether workers were leading such committees. With regard to the latter, it turned out that there were energy managers, at least in the large smelters, focused on managing energy efficiency programmes. This, however, excluded workers and was solely within the purview of management.

With all these dynamics, insights and commitments in place, NUMSA through its RDGs developed a dynamic action research plan (2013-2016) and agenda to assist the union develop its capacity and policy positions on climate change. The concrete objectives of the plan where to achieve the union's approach to transforming the energy system and achieving climate justice, that is:

- 'A society where there is democratic control and social ownership of the energy system

- 'A vision of the energy system that is consistent with our conception of socialism as an alternative to organise society and production' (NUMSA, 2013a: 6).

Out of this process NUMSA built important capacity inside the union. In practice the group of twenty-two original workers making up the RDGs has now shrunk to fifteen. However, the group is still dynamic and works more as one RDG rather than three separate sub-sectoral RDGs. It meets once a month around a certain topic, brings in people to present on various issues, and frequently visits workplaces. Such visits have included a solar manufacturing plant, a power station and wind parks. All of these seminars and study tours have contributed to building internal capacity in the union and deepened the internal dialogue about climate justice.

\section{International links and study tours}

Informed by the RDG action research plan and by NUMSA's commitment to build its collective union capacity, NUMSA reached out to and employed an international coordinator, Kolya Abramsky, one of the world's leading experts on renewable energy. Abramsky has written and edited important books on the renewables energy shift including Sparking a Worldwide Energy Revolution: Social Struggles in the Transition to a Post-Petrol World. His task in relation to NUMSA has been to ensure it is linked into cutting-edge international trends, research and networks that advance its agenda. As a high-level technical person he has also become a crucial source of advice for NUMSA.

Moreover, after COP 17 and given the growing concern by climate justice activists that the

Global Labour Journal, 2015, 6(3), Page 273 
UN-led process was not providing credible solutions to the climate crisis, there has been a growing shift in some countries to contest climate and energy policies. This shift has spawned initiatives to learn from strategic engagements in different countries. The Democratic Energy Initiative (NUMSA, 2012c), linked to Cornell University, is one such effort to assist unions find alternative energy pathways. The Democratic Energy Initiative has brought together the few unions attempting such engagements in the world for round-table discussions and to share experiences around attempts to bring about a just transition. NUMSA has been invited to join the Democratic Energy Initiative and has actively participated in its convened dialogues. Due to its participation in this network, NUMSA has made important links in the process, has brought back international insights and connected with other international experts.

In addition, through the World Federation of Trade Unions NUMSA participated in a dialogue with energy unions convened in Venezuela (NUMSA, 2012d). It used this engagement to understand what unions were doing, mainly in Latin America, about energy transformation. In 2013, NUMSA sent a group of five unionists from its RDG on a study tour to Mexico and Cuba. The purpose of this trip was to study the political economy of energy. In Mexico the union was keen to understand how the privatisation of energy supply away from a single national producer (similar to South Africa) changed the energy political economy. The role and negative consequences of energy reforms led by the private sector were scrutinised closely. The main lessons brought home to the union related to how renewable energy was being introduced, the structure of the bidding system, the tariff structures put in place and the nature of power purchase agreements. Beyond the technical aspects of private-sector-led energy generation, the union also came to understand how land dispossession and bureaucratically controlled vertical state practices (now privatised) undermined the development of socially owned renewable energy.

In Cuba, the NUMSA team spent time participating in the World Wind Conference and understanding the development of renewable energy in Cuba. At the conference the union engaged with leading experts from different sectors occupied with wind technology - industry, academics, NGOs and parastatals. Crucial for the union was learning how Cuba managed its transition away from dependence on fossil fuels after the collapse of the Soviet Union. The policies and structural changes in Cuba provided valuable lessons.

Moreover, NUMSA (2013d) has actively engaged the BRICS process around renewable energy. At a BRICS summit held in South Africa in 2013, NUMSA hosted a seminar with labour unions from the BRICS, progressive academics and movements to discuss renewable energy options in the BRICS countries. This engagement also served to build NUMSA's comparative insights on renewable energy policy and its challenges in the BRICS countries.

The process of learning from international experiences, networking and using this to build union capacity is ongoing in NUMSA.

\section{Developing union policy positions on climate change issues}

Harnessing the capacity of its RDG, its international links and study tours, NUMSA has consciously and collectively developed crucial policy positions on climate change issues. This entailed the following (NUMSA, 2013a):

- The RDG developed policies for NUMSA on the national energy mix and climate change, which entailed having a political school for its Central Committee on climate change issues. The union brought scientists and other technically informed speakers into this school. In addition, it took all its educators through a training programme on climate change at the University of Cape Town and ran climate change workshops for its Regional Executive Committees. This was followed by a bottom-up process of submissions from regions on

Global Labour Journal, 2015, 6(3), Page 274 
climate change, and ultimately led to the adoption of a climate-change resolution at its Congress in June 2012.

- Another area of policy development has focused on understanding renewable energy and the 'green economy'. To empower the union, an international conference on socially owned renewable energy was organised in February 2012. The recommendations from this conference went to the National Committee and the regions for engagement. This culminated in policy debate and resolutions at the union's June Congress.

- The union has had engaged deliberation and discussion on a proposed carbon tax for the country. In 2006 the national Treasury introduced a document on environmental taxes, by 2010 NUMSA presented its first discussion document, and in 2011 the union had its first workshop on carbon tax involving the Treasury. In 2013 the union developed a second discussion document, hosted a national workshop, produced a twenty-minute documentary resource on the merits and demerits of a carbon tax, sent this to regions and then consolidated the discussion at its National Executive Committee. In the end, five regions supported a carbon tax, three were against it, and one was flexible. The union currently has a position of conditional support for a carbon tax.

- In addition, NUMSA has shaped COSATU's position on socially owned renewables and climate change. It has also ensured that its own participation in a national climate jobs campaign, together with that of other COSATU affiliates, is both supported and endorsed by COSATU. In the main COSATU has endorsed NUMSA's position and the work done by other affiliates on these issues, and has also deepened its relations with environmental and climate justice campaigners (COSATU, 2011). ${ }^{6}$

- The union has taken forward a commitment to lead on greening its own buildings in accordance with resolutions adopted. Thus the union has refurbished and retrofitted its head office in Johannesburg as well as its buildings in Durban and Pretoria. It has introduced solar panels on the roofs of its buildings, water harvesting and other energy efficiency innovations.

\section{Advancing Elements of a Campaign for Climate Justice}

South Africa, particularly after COP 17, has experienced growing NGO-led campaigns around climate change. Many NGOs - such as the Climate Justice Network, Earthlife Africa, Greenpeace and Oxfam - have placed an emphasis on advancing climate justice issues through contesting state policy on coal-fired power stations and nuclear power. Crucial lobbying-based opposition, targeting the state and media, is being built on this front. However, these campaigning activities are not happening through a mass-based politics. It is in this context that NUMSA's climate justice campaigning has to be understood. It brings out a mass dimension, which not only involves workers but is being led by workers. A mass movement for climate justice, led by workers, has been broadly absent in South Africa and the leading green campaigning NGOs have not been able to achieve it. Thus, for the first time there is a real possibility of a red-green alliance.

To advance a union-led campaign for climate justice, NUMSA has drawn on its growing research capacity, its internal education processes, its developing policy positions and its strategic location. This has engendered three crucial campaign-centred focus areas.

\section{(i) Contesting energy efficiency and electricity price increases}

Given South Africa's carbon-driven energy economy, NUMSA's campaign planning has

Global Labour Journal, 2015, 6(3), Page 275 
prioritised intervening in energy efficiency and limiting electricity price increases. In both instances, NUMSA has tried to ensure that worker interests prevail while trying to skew national government policies towards a climate justice orientation. In the case of energy efficiency, NUMSA engaged Parliament's Energy Portfolio Committee around the question of the exclusion of workers and shop stewards in the implementation of energy efficiency measures in the economy. NUMSA has raised this issue starkly to ensure that the gains of energy efficiency are monitored through worker control at the point of production. To build its own capacity for this, it has developed partnerships with two universities to train shop stewards, namely Potchefstroom and Pretoria. This is ongoing.

With energy price increases, and cost increases more generally, capital has tended to cut back on labour and labour costs in response. Households have also experienced the squeeze of increasing costs, such that the crisis of social reproduction has been exacerbated. NUMSA, being alive to these challenges, has actively campaigned against planned electricity price increases by Eskom. In 2012, Eskom signalled that it would press hard for another round of electricity price increases, at least a $16 \%$ increase in electricity prices from 2013. NUMSA was opposed to this increase and took it up intensively as a campaign. As Eskom issued its application for a price increase to the national energy regulator, NUMSA responded internally and externally. Internally NUMSA activated its RDG to study the Eskom application. The RDG then asked Eskom to explain why it wanted these increases, and it hosted a five-day workshop to understand electricity pricing and clarify a NUMSA position. This position was then shared and developed in consultation with NUMSA regions and the national leadership. Time was also given to build capacity of its national office bearers through a workshop.

Externally, NUMSA took forward its campaign through pickets outside every public hearing in the country. It made presentations to every hearing highlighting the devastating economic and social consequences of Eskom's tariff structure. It also built an issue-based coalition of organisations involving churches, environmental NGOs, civic organisations and other interested parties. This coalition became extremely vocal and built mass popular support against Eskom's 16\% electricity price increase. In addition, NUMSA actively engaged the African National Congress (ANC) and its key ministers (in areas such as Energy and Finance), and thus forced a meeting between Eskom, the ANC, relevant ministers and NUMSA. In the end, Eskom was only granted an $8 \%$ hike in electricity prices.

Moreover, this campaign intervention shed light on another important dimension of South Africa's energy political economy. This relates to an 'energy buy-back programme' that Eskom has with big energy users. Essentially, in order to manage energy supply in the country, Eskom has been paying big energy users not to demand electricity. This buy-back programme has led to big users taking this financial benefit from government while forcing workers to take short-time work arrangements. In short, workers have been forced to manage the supply constraints on the national energy grid. NUMSA campaigned to expose this injustice, and has also demanded a scrapping of the buy-back programme.

\section{(ii) Influencing and monitoring solar water heater roll-outs}

The South African government has planned to roll out one million solar water heaters. This has been happening through various local government led roll-outs. NUMSA has prioritised this area as crucial for campaign work to ensure the roll-out limits imports and is skewed in favour of local manufacturers. In this regard, NUMSA pushed for and secured a commitment from government to ensure a special procurement designation to ensure solar water geysers have a certain level of local content (for example, $62 \%$ of low-pressure solar water geysers are to be sourced from local manufacturers). This position was secured at a summit involving manufacturers and government.

Prior to this, the roll-out of solar water heaters was based on a rebate model, with

Global Labour Journal, 2015, 6(3), Page 276 
manufacturers securing a rebate from Eskom after installation in local municipalities. Now, after building a consensus with manufacturers and the Minister of Trade and Industry, NUMSA has ensured an in-principle and on-paper commitment to a contract model linked to procurement. This is meant to ensure that Eskom buys solar water geysers in bulk from local companies and that installation happens at municipal level, through locally based installer cooperatives.

Thus far NUMSA has faced two challenges with this campaign intervention. First, the Minister of Finance has put aside R4.2 billion for a solar water heater programme, but has taken this programme away from Eskom and has located it in the Department of Energy. This has undermined the work NUMSA has done to lock Eskom into the new contract model for solar water heater roll-out. NUMSA has tried to leverage local government, through former NUMSA members holding political positions, in an effort to influence this process from below.

The second challenge that NUMSA has faced is attempts by large metropolitan governments like the City of Johannesburg to bypass or avoid the special procurement designation around local content for solar water heaters. Johannesburg's energy supplier to consumers, City Power, has attempted to rush through a tender with an international supplier before the designation for local procurement came into place. NUMSA responded by taking the City Power to court, demanding disclosure on the criteria used for awarding the tender. Numsa's position was informed by meetings with communities to document problems with imported solar water geysers. This strengthened its case.

\section{(iii) Advancing socially owned renewables}

The third campaign-centred focus area that NUMSA highlighted was socially owned renewable energy in the national energy mix. In this regard NUMSA has tried to open two fronts for socially owned renewable energy generation rather than generation led by the private sector. The first has been monitoring the existing bidding window and process to watch for gaming and to influence government to think about alternatives. In this regard the union set up 'rebid watch' to monitor the renewable energy bidding process. While this was an important initiative, the union did not have the necessary and dedicated capacity to utilise this intervention effectively and it has limped along without reaching its potential.

The second front on which NUMSA is pursuing renewables is by mobilising resources and laying the basis for pilot projects. In this regard the union has been able to ensure that R1 billion from the metal industry's pension fund (the second biggest pension fund in the country and the largest in the private sector) is dedicated to renewables. However, this financing stream is not for socially owned renewables, but for local content and manufacturing linked to renewables. In this regard the union has been thinking about financing more seriously, both to influence the metal industries' pension fund but also to think through funding issues for a transition to socially owned renewables. In the union resolution on socially owned renewables there are three potential sources: public investment, revenue streams from hydrocarbons (hence the carbon tax), and redirecting worker pension funds. In this regard the union is at a frontier trying to find the most appropriate financing streams.

At the same time, securing pilots has been a crucial challenge given the power of large corporates, including transnationals, in securing bids for renewables. This has prompted the union to explore various possibilities and entry points in the renewable energy value chain. For example, the union is considering buying equity in the only South African company that manufactures wind turbines. In addition, consideration is being given to purchasing a wind turbine as part of a cogeneration pilot project. All of this is aimed at building experience, leverage and capacity to advance socially owned renewables. Beyond government's renewables window, there is still the possibility for the union to explore socially owned renewables on a scale and level outside the

Global Labour Journal, 2015, 6(3), Page 277 
government framework. This remains a challenge for the union.

\section{Challenges}

While NUMSA's worker-led climate justice campaign has been novel, strategic and a work in progress, it does face numerous challenges that will likely affect its ultimate success.

First, while NUMSA's interventions against electricity price increases and monitoring solar water heater installation has intersected with various social forces and built solidarity links, this has not translated into building a campaign base and rolling action. Instead the campaign interventions have been issue-centred and have dissipated after advancing the particular campaign agendas. For instance, winning community support against poor quality imported solar water heats should have been sustained until NUMSA clinched a firmer commitment from government on local manufacturing content. This is a challenge for NUMSA if its campaigns are to achieve wider traction for transforming the energy system.

The second challenge faced by NUMSA relates to 'locking in' a neo-liberal state from below. While important strides have been made in shifting Eskom towards a 'contract model' for solar water heater roll-out, this is being undermined by various forces in the state including the Treasury. All of these developments are conspiring against NUMSA, which has prompted the union to restrategise and look for opportunities to influence solar water heater roll-out at local government level. It is possible that if NUMSA manages to secure leverage over particular local governments this can change the way local government procures solar water heaters and can even change the role of renewables in local energy mixes. It is possible from below to displace the national cap on renewables, within the energy mix, by using local government distribution powers over electricity to bring in renewables.

The third challenge facing NUMSA is the way in which government has approached renewable energy policy and implementation. The government's commitment to a private-sector-led approach, as part of a competitive bid system, has allowed big corporations to dominate the renewable energy roll-out in the country. This has squeezed out smaller players, and most importantly reduced space for socially owned renewable energy. NUMSA, however, has not given up on the policy fight to create space for renewables. It is regularly engaging government ministers on the need for socially owned renewables and the need to move beyond the private-sector-led competitive bid model of renewable energy roll-out. At the same time, the South African government has shown greater commitment to reviving its nuclear build programme as opposed to building a dynamic renewable energy sector based on socially owned forms. This is an opportunity for NUMSA to build a broad civil society coalition against nuclear energy given its exorbitant costs, currently estimated at over one trillion rand, which is sure to bankrupt the South African state. Such an anti-nuclear campaign could easily be married to the failures of electricity supply by Eskom, with South Africa increasingly experiencing rolling blackouts (estimated to last for the next ten years or more given supply-side challenges), and with a call for renewable energy alternatives and an end to the national cap on renewables. Moreover, NUMSA is looking to harness the metal industry pension fund and its union investment arm to chart a new way forward for renewables investment. It is still too soon to assess this, but if the metalworkers of South Africa develop the capacity to stimulate socially owned renewable energy roll-out, outside of government's private-sector approach, this would mark a major shift in union politics and practice around the just transition.

Fourth, NUMSA is a manufacturing union that organises mainly manufacturing-sector workers. Building support and unity for collective trade union movement positions on climate justice is crucial. This means winning over workers involved in fossil fuel extractivism and production value chains to a conception of the just transition. While NUMSA was affiliated to

Global Labour Journal, 2015, 6(3), Page 278 
COSATU through which it could potentially build common union positions on climate justice, as with mineworkers involved in coal extraction and with unions involved in the chemical sector (such as SASOL, the fuel-from-coal producer), and workers involved on farms that are being organised into bio-fuels production, this was easier said than done. For instance, the National Union of Mineworkers (NUM) has a very conservative view on climate change and the just transition, in order to defend jobs in the coal industry, which merely echoes the neo-liberal position and resource nationalism of the ANC state (Bennie, 2013). However, NUMSA was expelled from COSATU in November 2014, in the main because of its opposition to the neo-liberal positions of the ANC government, despite the dominant faction in COSATU claiming it was expelled due to poaching members from other sectors. The purging of NUMSA was a not a clean process, with deep divisions cutting across all unions in the federation and with eight affiliates standing with NUMSA. COSATU is currently at an impasse and is likely to split. In this situation NUMSA's politics of climate justice among the working class faces numerous challenges that can only be resolved through a new political project, led by workers, and which speaks to the challenge of strategic alliances.

Fifth, and as a corollary to the above, NUMSA is now leading a process to build a movement for socialism, which could include the establishment of a workers' party to contest state power. As a first step in this process NUMSA is busy establishing a United Front (UF) of communities and workers. The NUMSA-led United Front is taking root dynamically and is poised to reap the benefits of NUMSA's attempts to reach out to communities around electricity price increases, socially owned renewables and solar water geysers. In a recently released statement by the UF working committee, it has foregrounded the crisis in Eskom and rolling blackouts and has called for a civil society conference on the energy crisis. ${ }^{7}$ Both the accumulation of mass forces inside the UF process and the attempt to take on the state on the energy crisis holds out immense potential to bring together a red-green alliance. The convergences NUMSA built with leading environmental justice NGOs, in its earlier fight with Eskom around electricity price increases, its links with the climate justice movement developed during COP 17, and its evolution of a socially owned renewables energy approach together with the opportunities for opposition to nuclear power in South African society hold out the exciting prospect for strategic convergence around a red-green alliance. If NUMSA gets this right, the red-green alliance led by workers could constitute the heart of a new strategic bloc for a new left project in the country which advances a just transition and the ecological restructuring of the economy, state and society. Such a transition and left project has to be about deep transformation and can only be realised through a programme for Democratic Eco-socialism that ensures society turns away from the destructive rationalities of capitalism, such as growth, endless accumulation and competition. ${ }^{8}$ At the same time, this requires a new labour politics, beyond productivism, that promotes ways to sustain life and society.

\section{Conclusion}

NUMSA is the most advanced union in South Africa and Africa in its approach to climate justice. It is pioneering a transformative unionism expressed through an attempt to think about systemic alternatives to confront climate change, build red-green alliances from below, advance a just transition as part of addressing the climate crisis and trying to deepen participatory democracy. It has demonstrated this in very serious ways through building an education-centred commitment and politics, while taking forward a climate justice campaign on three crucial fronts. First, the union has made a crucial impact on energy efficiency by ensuring that these gains are linked to worker control. Second, it has limited electricity price increases by Eskom in a context in which South Africa is experiencing a crisis of social reproduction. Third, it has exposed the parasitic role of big energy users by showing how they have profited from government subsidies as part of cutting back

Global Labour Journal, 2015, 6(3), Page 279 
energy supply while squeezing workers with short time.

With its campaign focus on solar water heater roll-outs, NUMSA has won a consensus for local content and local provisioning. It has also placed immense pressure on government entities to consider local procurement. Finally, in terms of renewable energy, NUMSA has pioneered a transformative notion of socially owned renewable energy in South Africa. While it has challenged a neo-liberal state committed to private-sector-led roll-out, NUMSA has opened the way for an alternative approach to energy in South Africa consistent with climate justice. As it redirects finance and experiments in the renewables value chain, the union is building the capacity to advance a transformative class struggle for a South Africa committed to a deep and just transition to achieve democratic eco-socialism.

In all of this NUMSA is building a politics that connects the interests of union members with the interests of society and nature. It is challenging class solutions that reduce nature to a site of accumulation while workers and the poor pay the price of climate change. Various challenges come with this approach including union capacity building, alliance building, an unresponsive green neoliberal state, the current divisions in COSATU and the limits of issue-centred campaigning. However, despite these challenges NUMSA is breaking ground and opening up new possibilities for unions and for transformative social change in an age of worsening climate shocks.

\section{NOTES}

${ }^{1}$ I would like to thank Dinga Sikwebu, the national policy and education officer of the National Union of Metalworkers of South Africa. Not only did he provide me with an extensive interview (21 August 2013), but he also supplied me with all relevant union documents that enabled this research. I would also like to thank Professor Jacklyn Cock, a cofounder of Earthlife Africa, for an interview (1 February 2015). I have studied primary union policy documents, newspaper articles and other relevant secondary sources for this article. Finally, in a NUMSA social theory class I teach at the University of the Witwatersrand I have had discussions with NUMSA shop stewards about their campaign, the climate jobs campaign and about other systemic alternatives. All of this informs the contents of this article.

2 Angus (2010) and Bond (2012: 187) recognise systemic transformation as the centrepiece of the climate justice movement and its politics, while recognising that this is informed by various political traditions from social justice activists, eco-socialists, radical indigenous movements to progressive governments like Bolivia.

3 These are the latest data from the Draft National Greenhouse Gas Inventory for South Africa. This is cited in the National Development Plan - 2030 (South African Government, Undated: 206). Verifiable and credible data on greenhouse gas emissions is a serious policy challenge in South Africa.

${ }^{4}$ The price increases to residential consumers have had a serious negative impact on household incomes. However, the increases have not effectively targeted the mining and industrial sectors, with companies often receiving reduced prices.

${ }^{5}$ For example, in South Africa the Bisasar Road landfill has been extensively studied to show how, by locking this site into the Clean Development Mechanism, it has prolonged various health hazards experienced by neighbouring communities.

${ }^{6}$ In my interview with Professor Jackie Cock, a cofounder of Earthlife Africa, one of South Africa's leading environmental justice NGOs, she confirmed that COSATU has convened a policy group on

Global Labour Journal, 2015, 6(3), Page 280 
environmental issues and has brought various green campaigners and NGOs into this space.

${ }^{7}$ The UF interim working committee was formed in December 2014 at the UF launch preparatory meeting. I was in attendance at this meeting. It issued a statement on 29 January 2015 entitled: 'Progress on Building the United Front and Call for a National Day of Action (25 February 2015) for a Budget that puts People before Profits!' This statement calls for a civil society conference on the energy crisis.

${ }^{8}$ There is an unrecontructed Marxist-Leninist current inside NUMSA which believes in modernising industrial socialism. It is one current among many, and is constrained by the worker control politics of NUMSA. However, if the NUMSA-led United Front unites red and green forces in its struggle around the energy crisis, this could unhinge some of the ideological dogma among some in NUMSA.

\section{REFERENCES}

Abramsky, K. (2010) Sparking a Worldwide Energy Revolution: Social Struggles in the Transition to a Postpetrol World. Oakland and Edinburgh: AK Press.

Angus, I. (2010) The Global Fight for Climate Justice. Winnipeg and Sydney: Fernwood Publishing and Resistance Books.

Bennie, A. (2013) Questions for Trade Unions on Land, Livelihoods and Jobs. In Trade Unions in the Green Economy: Working for the Environment, edited by N. Räthzel and D. Uzzell. London and New York: Routledge.

Bond, P. (ed.) (2011) Durban's Climate Gamble: Trading Carbon, Betting the Earth. Pretoria: UNISA Press.

Bond, P. (2012) Politics of Climate Justice: Paralysis Above, Movement Below. Pietermaritzburg: UKZN Press.

Cock, J. (2013) The 'Green Economy': A Sustainable Development Path or a 'Wolf in Sheep's Clothing'? Paper presented at conference 'Land Divided: Land and South African Society in 2013 in Comparative Perspective', 25-27 March, 2013, University of Cape Town.

Congress of South African Trade Unions (COSATU) (2011) COSATU Policy Framework on Climate Change: Adopted by the COSATU Central Executive Committee, August 2011. Available online at http://www.cosatu.org.za/show.php?ID=5679.

Kings, S. (2013) Carbon Tax Will Power SA's Drive to Clean Up Its Act. Mail \& Guardian Business, 8-14 March. Available online at http://mg.co.za/article/2013-03-08-00-carbon-tax-will-powersas-drive-to-clean-up-its-act.

Newmarch, J. (2013) Does Money Grow on Trees? The Role of Climate Change Finance in South Africa. Unpublished master's research report, Development Studies, University of the Witwatersrand, Johannesburg.

National Union of Metalworkers of South Africa (NUMSA) (2011) Report on the Launch of Energy Research and Development Groups (RDGs). October 2011. Unpublished report.

National Union of Metalworkers of South Africa (NUMSA) (2012a). Building a Socially Owned Renewable Energy Sector in SA. NUMSA $9^{\text {th }}$ National Congress, June 2012. Unpublished

Global Labour Journal, 2015, 6(3), Page 281 
report.

National Union of Metalworkers of South Africa (NUMSA) (2012b) Climate Change and Class Struggle. NUMSA $9^{\text {th }}$ National Congress, June 2012. Unpublished report.

National Union of Metalworkers of South Africa (NUMSA) (2012c) Global Initiative on Trade Unions for Energy Democracy (TUED). Unpublished document.

National Union of Metalworkers of South Africa (NUMSA).(2012d) Report from the WFTU TUI Energy Congress. Unpublished document.

Räthzel, N. and Uzzell, D. (2013) Trade Unions in the Green Economy: Working for the Environment. London and New York: Routledge.

Satgar, V. (2014) South Africa's Emergent 'Green Developmental State'? In

The End of the Developmental State? edited by M. Williams. Pietermaritzburg: UKZN Press.

South African Government (Undated) National Development Plan - 2030. Pretoria: National Planning Commission.

South African Government (2011) National Climate Change Response White Paper. Pretoria: Department of Environmental Affairs and Tourism.

Urban Earth. (2012) South African Carbon Snapshot. Available online at: www.urbanearth.co.za.

Winkler, H. (Undated) Report on Long-Term Mitigation Scenarios. LTMS Project Report. Unpublished report.

\section{BIOGRAPHICAL NOTE}

VISHWAS SATGAR is a senior lecturer in International Relations at the University of the Witwatersrand, South Africa. He has published on systemic alternatives (The Solidarity Economy Alternative), Africa's political economy and on South Africa (COSATU in Crisis). He currently edits the Democratic Marxism book series (Marxisms in the 21st Century, Capitalism's Crises and forthcoming The Climate Crisis and Just Transitions) and is currently working on a book focusing on Africa's globalising political economy. He has been an activist for over thirty years and was a co-founder of the Democratic Left Front, the South African Food Sovereignty Campaign, the Solidarity Economy Movement, and the Vote No Campaign. For the past six years has been teaching a social theory course at Wits to shop stewards of the National Union of Metalworkers of South Africa. [Email: Vishwas.Satgar@wits.ac.za] 